\title{
The Bald Ibis From Eagle Understanding A Historical City From The Traditional Craftmanship Language
}

\author{
Dr. Aytul Kasapoglu \\ Professor of Sociology at Baskent University, \\ Department of Sociology.
}

\begin{abstract}
The name and purpose of this work was inspired by the fact C.Wright Mills (1959) described sociology as an "Intellectual Craftsmanship" . The main aim is to examine traditional craft figurations (Elias, 1939; 2000) in a historical city (Mugla), which I find appropriate to explain with workshop metaphor. Paul Thompson (1978), when he says to hear the voice of the past, underlines the importance of the bottom up historical approach, ordinary people and everyday events in the construction of a more democratic and egalitarian future. In this study, it was paid attention to the changes in both time and space to be treated in a process and holistic manner by rejecting "essentialism " and "dualities". In this study, it has been tried to make appropriate analyses by using the biographical narratives formed by the oral history technique. The originality of this research, based on the theoretical approach of Relational Sociology, is also here.
\end{abstract}

Keywords: Relational sociology, figurational sociology, grounded theory, oral history, Turkey.

\section{INTRODUCTION}

Historically, before declaring October 29, 1923 Republic of Turkey, 24 July, 1923, The Treaty signed in Lausanne by Grand National Assembly representatives of Turkey, Great Britain , Italy, France, Greece, Bulgaria, Portugal, Belgium, Yugoslavia and Switzerland. Called Lausanne Agreement (1923) made in addition to the " The Protocol Convention Concerning the Exchange of Greek and Turkish people. According to the protocol the Turkish population subjected to Mubadele/Exchange with Greek population in Turkey. People in this exchange, is also called 1924 Muhacir (Emigrants) in Turkey. In 1924, the Greeks migrated from the centre of Mugla to Greece. If the relational sociologist was told with the terminology of Harrison White, this Mubadele /Exchange was a" turning point". There are also other turning points; the second is the mechanization and mass/serial production since the $1980 \mathrm{~s}$ and the transformation of craftsmen /artisans into tradesmen .

The third is urban transformation due to modernization. The last turning point was the renewal project of Mugla city between 2010-2012. Inspired by Foucault (1972), it is also possible to say "breakdown point" as the beginning date of significant changes. Because the Muslim people in Mugla mostly engaged in agriculture and animal husbandry, trade and craftsmanship were carried out by the Greeks. Therefore, the Greeks who left with forced migration in the Mubadele /Exchange have left a significant gap. Those who tried to remove this gap and even prevented it from turning into a trauma had been the remaining Muslim Turkish population as their apprentices.

These are the aging craftsmen who have been defeated at the end of the industrialization and modernization in poverty and necessity. Because the newly established order meant more capital and bureaucracy. However, most of the old craftsmen, who did not even have primary 
school graduates, had neither the strength nor the ability to carry out the procedures that should be followed in the official departments, in particular the tax.

Due to the massive impact of mass production and modernization, the demand for goods and services produced by Arasta Bazaar was left to survive thanks to the state-owned (Bagkur) pensions. In fact, when the shoemakers and tailors were transformed into repair shops, the shops lost their qualifications to become jobs and earnings, and their owners began to turn into a means of socialization. Among the residents of the old bazaar (ARASTA), there were those who told him that he had come to chat with shopkeepers instead of a coffeehouse. There were also few who confessed that his shop was the reason for going out at home to avoid getting bored. All these signs were indications that the alarm bells were ringing and that the situation was so urgent that it would not be postponed tomorrow. It was necessary to make state and and non-governmental organizations, especially the public and local administrators, to hear people from all sectors.

It would not be wrong to say that writing history is more difficult than making history. This work is important because it relies on the study of oral history, which describes the everyday lives of ordinary people, rather than elites.

While it takes weeks to take a look at the history of Muğla, understanding and commenting on it is serious enough to take years. Therefore, it is actually a practical and realistic approach to say that with a few paragraphs, the region has a very rich history and that in the past there is very important Anatolian civilization like Caria. Like all Anatolia, this region deserves the necessary attention and effort to understand the rich heritage and the value of the various civilizations built upon each other. Craftsmanship and trade in the context of the so-called Silk Road is on the trade route and other sea and commercial trade routes to make the economic history of Mugla and its surroundings more important.

Muğla and its surroundings are also called as Caria. There are different opinions about who the Carians are. According to the historian Herodotus, the Carian's came from the island of Crete to exile. According to some sources, the Carians are indigenous people of Anatolian origin and are mentioned among the participants from Anatolia against Greeks in the Trojan War. Based on Homer and his Epic of the Iliad it can be said that the barbaric language spoken by the Carians is as much a dialect of Greek language as it is; against the Hellenic- centred thesis, the views of the Carian language as an Anatolian language are quite common (Buluç, 1993; 2006). As famous Turkish author and historian Cevat Şakir Kabaağaçlı (1890-1973), who was known as the Fisherman of Halicarnassus, insisted, all the basis of the Greek civilization is Anatolia; therefore, we must think that Anatolia is the cradle of all civilizations and his thesis is supported in this context.

As the Aktüre (1993) stated, Mugla is in a socio-economically advantageous region. Timber management was carried out by the Turkmens, also called Tahtacilar from the Taurus. In addition, the semi-processed agricultural product used in the dye and pharmaceutical industry, called shallow oil in the region, was sold to Rhodes by Mugla Jews. Copper, chrome, manganese and sandstone and salt are also produced and sold in the region. Mining and forestry products (timber production) were the most important sources of income for the region. In the Mentese region, soil-based craft testing and the construction of the censer and lime trade were also important. Because limes produced from lime quarries were an important export product. It is also understood from the documents that the capital obtained from lumber and lime transformed into investment by the Greek and Turkish partners in İzmir (Aktüre, 1993). In other words, the capital accumulated in the region could not be transformed 
into industrial production as they did not have the necessary advanced technology and this point has become particularly important later.

Because when the Greek and other non-Muslims engaged in this trade were withdrawn, subsistence production was replaced market oriented production. The closed economy is therefore the production that will bring income to the household by raising the product needed in the family or selling it in the nearby market. If this production is connected to the merchant, it is also called home industry. While there is no large-scale industry in Muğla, the small-scale household industry is more common. This type of home industry has the potential to integrate with the capitalist system (Tekeli, 1993/2006: 146).

On the other hand, in Mugla, fruit and vegetable gardens are an indicator of the self-sufficiency and even closure of the city economy. Vegetables and fruits produced in the immediate surroundings against the risk of deterioration are brought to the city markets and sold. As Tekeli (1993: 146) stated, the most important phenomenon in Mugla is the highlands where families go in summer. The most important of these is the Karabağlar Plateau which dates back to 300 years ago. In the Karabaglar Plateau, where the families' needs were met, the gardens so called as "yurtluk" (small parts of land). According to Çınar (2010), approximately 50,000 hectares of land in Karabağlar were divided into 15,000 parts . Each "yurtluk" had three to four acres of land. Although the same height as Mugla, the region referred to as the plateau was a place of production in which people went to the beginning of summer and returned to the autumn, where agriculture, animal husbandry and winter preparations were made. In these gardens, all kinds of vegetables and fruits were grown, even sheep would be fed for meat. While the families were returning in the autumn, they would meet their winter needs with the dried vegetables, tomatoes, pickles, and roasts.

As underlined by Tekeli (1993) and Çinar (2010), the main reason of the relationship between urban Mugla and rural areas was this highland culture. The region, where the number of coffee houses is around 20, is more vibrant and active until the 1960s. There were all kinds of places to be used in the summer around coffee houses, such as grocery, barbershop, repairmen and farrier. Cafes were both cultural and commercial canters. Around the cafes, there were masjid, restaurant, bakery, butcher shops. Because in the summer, all of the tradesmen who could not shelter from the heat in the center migrated to Karabağlar. There was a multicultural population of Yörüks, who chose this place as a place of residence for the villagers from the Mugla region and the peasants from the surrounding villages. The nomads had chosen the Karabaglar as the accommodation area at the end of spring and vineyard. It was their greatest characteristic to have different groups together to produce, have fun and live. This also shows that the features that make common life possible, such as help, tolerance and trust are highly developed. Traditional entertainments such as horse racing, melon festival are also indications that this culture has been transferred from generation to generation. The coffee houses were not only a meeting, but had a remarkable function as a centre of peasant, urban and nomadic communication, and important policies. However, it will not be wrong to say that Karabaglar have lost their past functions in a great extent in general, and that it is temporarily available for picnics in the gardens rather than the city centre. It is clear that the purchase and repair of the coffee house named Keyfoturağı by the Municipality of Mugla is a gate of hope for the future of the Karabaglar.

On the other hand during the 19th century representatives of Ottoman administrative bureaucracy who came to Muğla and trade capitalist rich Greeks were closer to each other. They were living in the in Konakaltı and Saburhane, open to the road, integrated into the street, in the extroverted houses. On the other hand, the Muslim people of Muğla were living in 
houses that were generally turned into the street and were closed to the street. While the Greeks and the Ottoman bureaucracy stayed in the city in summer and winter without going to the Karabağlar Plateau, the arrival of the native Muslim population to the plateau created differentiation in the context of both spatial differentiation and cultural lifestyle (Aktüre, 1993). In the 19th century, the Government House, Military Barracks and Telegraph House were built close to Konakaltı Square. Arasta Bazaar was the centre of economic activities.

\section{THERORETICAL BACKGROUND : RELATIONAL SOCIOLOGY}

This study was prepared in accordance with the basic principles of Relational Sociology (Kasapoglu, 2016). In other words, the theoretical perspective of the study is relational sociology. For this reason, it was tried to look at the process by defying the essentialism as much as possible.

Because many things have changed from past to present, for example, traditional crafts have disappeared or have begun to undergo metamorphosis to survive. For example, since the demand for hand made shoes and dresses came almost to a halt, the craftsmen in this area started to earn their livelihood by tinkering. In addition, the new shoes, instead of repairable leather material, synthetic and disposable-style often eliminates this option. Because the hand labour is expensive and often poor quality products are preferred. Repairers have also started to suffer from livelihoods.

It is not possible to live by producing goods for people who do not have a standard size of shoes and clothing. In the past, the bread between halva was common, while young people eat fast-food and other traditional food and drink culture have passed. Places selling sandwiches, toast and cola drinks have become widespread. On the other hand, there are still survivors who have managed to hold on to evolution. Due to the tradition of dowry, there is still demand for handcrafted bedding quilts and embroideries. Likewise, starting from the door knockers of the hotels-motels or mansions, the choice of copper in other decorative objects led to the standing of copper. However, even though these masters have managed to mobilize their creatures and all their skills, they cannot find an apprentice, so the craft of handcrafted coppersmiths, as in other parts of the country like Gaziantep, has a high risk of being devalued by turning into mass cheap fabricated copper pot production instead of the production of valuable art.

As the relational sociological studies were mostly carried out by induction and problemoriented, the bottom-up data were collected in this study. For example, we tried to learn from the routine actions of the traditional tradesmen who are still working by applying the bottom up approach, not from the history of heroes or events. In addition, since there is an extensive research about elites or notables throughout Turkey carried out by Durakpaşa and her research team (2008), our study has become even more important to understand the changes in the lives of ordinary people's daily routine movements. It may even be said that similar to the famous British sociologist, Richard Paul Thompson, born in 1935, published his work as" The Voice of the Past: Oral History" in 1978 , we also tried to carry the history from below to the centre. Certainly for the future, re-building and understanding of the past has become more important. Especially oral history as a interview technique has gain importance in the world as well as many workers in Turkey and even resistance in Mugla Yatagan Thermic Central has been guiding by the data derived from oral history. Later on the oral history has been made to document the workers' struggle against the privatization of the Yatağan Thermal Power Plant (Güngör and Şahin, 2007). 


\section{The process of analysing figural sociology:}

Famous relational sociologist Norbert Elias $(1939 ; 2000)$, whom we used most in trying to understand the process of extinction of the traditional artisans of Muğla, in his early years was calling his study as Figurational Sociology. On the other hand, it is useful to recall that relational sociologists have developed new concepts by finding the basic concepts of classical main stream sociology such as structure, individual and society as inadequate. Figuration in Elias and " habitus " or " field / camp" in Bourdieu have always been introduced with this need. As a result, Elias uses the concept of "figuration" because the existing concepts of sociology are insufficient in describing the weave of interdependence between the individual and the society.

According to Elias (1986), figuration is a social structure consisting of a number of individuals who are connected to each other through a series of positions, norms and values. A Figuration is a framework that organizes and directs communication and the behaviour of a group or individual action. For us, the craftsmanship in Mugla was considered as a figuration. As a subculture of craftsmanship, it is in a position that exceeds the structure and the individual of many craftsmen / tradesmen and the rules of learning and production of different crafts.

It should be kept in mind that Elias's process-oriented methodology is in fact a three-step process of reconstructing a-) macro, b-) micro- and c-) sociogenesis. Because, as Paul Thompson (1978) points out, it is the reconstruction of the past through information gathered from the bottom by oral history through ordinary people who are not overly taken care of.

In fact, there is a process of re-establishing the forgotten memory in a particular process. The focus of our work is the artisans in Mugla. In the center of Mugla, the migration of the qualified citizen, was forced by the Convention on the Turkish and Greek Population Exchange, which was signed in Lausanne on July 1923. It is possible to read this as an important "turning point" or break down point (White, 2008) in the craftsman figurations of the city. As a matter of fact, 1,200 Greek population, whose exact number is controversial in official records, left the centre of Muğla and only seven of them were exchanging Muslim Turks from Western Greece (Kurtulus, 2007). Some of the resources of the city population, which was 10,000 before the First World War, claim to be $10 \%$ and some other sources are $20 \%$ Greek (Akça, 2002; Aladağ, 2007; Kurtuluş, 2007). It was inevitable that the absence of the arrivals in the same ratio would create significant differences in figuration. Since there are no new craftsmen, it can be said that the domestic Turkish Muslim population, who was an apprentice beforehand, continued their traditional craft. All these events created changes in the figuration, for example, no new houses could be built in the city because of the lack of a stone master, and the marriage was postponed for two years (Akça, 2007: 103).

Since the society is in constant change, some theories such as system theory and structural functionalism will not be of benefit, so we focused on explaining social processes in Mugla. Questions in oral history studies are always directed to do this archaeology. Only with the awareness of the fact that dealing with today limits sociology, the post-modern views dealing with now / today and here and now are also distanced. The reason is that many sociological studies only do empirical work by breaking the connection with the past and this is an important limitation. Sociologists should look at the past not only because it is interesting, but also because they will provide them with greater awareness in understanding contemporary problems. Therefore, in our study, we tried to bridge the gap between the past and the future by collecting historical (diacronic) data as well as simultaneous (synchronic) data. Instead of static sociology based solely on descriptions, we tried to look at a long-term perspective, 
although not as much as Elias, who aimed to develop medium-sized and societal theories by making sociology based on process -oriented and dynamic.

It is possible to talk about many issues and problems that we have to overcome during our work. The first one is the defeat of the duality and subjectivity. In the study, we did not think that phenomena existed outside of us, or that subjectivity destroyed phenomena as rigid positivists suggested. More. N. Elias (1939; 2000), without accepting a static subject-object relationship, we have seen that even in the process of acquiring knowledge, the subject has changed, even the subject itself is changing, that is, we are in the "involved subjectivity " with Elias's terminology. Because before and after the oral history interview about Muğla , and as we deepened our attitudes and behaviours also changed.

In our studies, three types of subjectivity (a-) "verstehen", b -) "partiality "and c-)“ perspectivity" ) that were categorized by Elias were encountered in the most partiality and deep interpretations. The destruction of the memory of the person interviewed here was important. However, to prevent such subjectivities from destroying research, historical, economic and cultural conditions and collected data were revised to ensure consistency between the facts.

As Elias underlines, factual questions often carry political content, and therefore rarely remain detached from political issues. In other words, in reality, "interpretation" and" partiality" are intertwined. In the final analysis, however, it was possible to ensure a tense balance between research purposes and detached (objective) analysis as much as possible. While it is not possible to completely lose subjectivity, measures has been taken not to make mistakes in the subject of partiality and perspectivity. The collected data is read again and again to eliminate the contradictions and to fill gaps between the data and historical conditions.

It is important for a researcher to explain the reasons for choosing a theoretical framework to guide his empirical research to reduce his partiality. In grounded theory studies, the data and theory are closely linked. Because it is impossible to collect and interpret data without a theoretical focus. In the same way, the reliability of the research cannot be evaluated without a conceptual framework showing how data and theory can connect to each other. Therefore, we have always tried to protect our relational sociological perspective. We approached critical as relational sociologist "theoretical and "empirical" differentiation, which we think emerged as a result of intensive empirical work.

The point that needs to be underlined is that the art of craftsmanship we have studied has been taken place in a certain time and place. Since most of the studies we conducted in the centre of Muğla city centre are local history studies, it is also a "spatial analysis". It is even possible to say that spaces have an active language as well as being passive. As a matter of fact, when we look at the history of Muğla, it is understood that the Saburhane was in the Rum neighbourhood and the Tabakhane was a Muslim neighbourhood. We can say that this type of settlement is spatial differentiation based on pre-nation religion and ethnicity, and this observation also applicable to Europe. Another observation is that the rich and poor Greeks used to live in the same neighbourhood, then the rich regardless their ethnicity and religion, in the city, in different places, for example, built modern houses in Konakaltı neighbourhood.

\section{METHODOLOGY : GROUNDED THEORY IN DATA ANALYSIS}

In this study, two of the five qualitative traditions mentioned by Cresswell (1998) were applied to a large extent. First, the field-based theory was developed to identify the problem that 
bothered us. For this purpose, preliminary interviews were made with the people carrying the problem and the related literature was read and familiarized with the problem .

Theoretical sampling was used to determine the persons to be interviewed in the field. The theoretical sampling is in fact choosing the appropriate examples fo the purpose of the research. In other words, instead of el probability (random) sampling in quantitative research, the purposive sample was chosen in qualitative research.

Although the information gathered from the field is based on the fact that the information is gathered by accumulation, the previous studies have been systematically evaluated. Thus, the shortcomings and inadequacies of the existing theories have been shown and the importance and the rationale of the work to be carried out has been revealed.

The notes held in the field are very important. Interviews in the field were noted or recorded and resolved later. In addition, observations made in the field were also written.

Comprehensive Cultural Sociology (Edles, 2002) has guided us in our grounded theory approach that takes structure, individual and culture together.

More than one qualitative tradition was used in the study. As in biography, narratives are constructed with the help of metaphors. These metaphors also helped to name the research.

In a research it is important to develop "conditional matrix". Knowing the historical, economic, social and cultural conditions that led to the emergence of the research problem, facilitated the writing of the research questions and the development of categories for coding. In particular, the literature has been reviewed for the qualitative matrix information (Glaser and Corbin,1990)

As is known, every sentence can be coded in "open coding". On the other hand, since the "axial coding" demanded intense intellectual accumulation as the stage of interconnecting a large number of categories, the relevant literature and discourse were reviewed (Glaser and Strauss,1967).

The "core concept" may sometimes not be the only one. Multiple concepts can be seen equally important. As a matter of fact, two concepts were found in Muğla study. For example, the "lack of support" of the small producer, including artisans, and the "lack of capital accumulation".

In the beginning, it is undoubtedly forgotten that the literature review to reveal the rational of the research should definitely make use of it when discussing the findings.

The number of people to be interviewed was determined by the continuation of the negotiations until the information was repeated. In other words, interviews were continued until saturation was achieved, and interviews were terminated when there was no possibility of a new or different response.

Although the collected data were large enough to enable quantitative analysis, no quantitative analysis was performed, but the findings were made visible as figures and tables.

The assessment of the validity and reliability of the grounded theory is also extremely important. Since it is largely dependent on the researcher's effort, how to choose the appropriate and original theoretical sample from the beginning; how basic categories are 
revealed; the question of how data is collected and how the core concept is selected is important to assess the quality of the grounded theory research.

\section{ORAL HISTORY AS DATA COLLECTION TECHNIQUE}

An oral history is a technique that includes personal memories, causes and effects of events. This information may be collected through the tape recordings of interviews with the relatives of the deceased or the individuals who are still alive (Cole, 1994; Plummer, 1983).

Interviews conducted in the research were objectively interpreted with limited comments but a strong historical background of the subjects with interesting metaphors or narratives . During the research, many metaphors were recorded. For example, a saddle man likened himself to the "animal tailor" and the silversmith profession to raising children. Some copper seller themselves, such as "bald bird" feel lonely, while some "harmonious music" they said they do. When a tinker used the metaphor of the journey, the blacksmiths described their work as tree-raising and "gold bracelet". A tailor saw himself as "ant," and blanket producer described him as a "wedding dress". Watchmakers had chosen the metaphors of the "plane tree" and "mirror". While an electrician described himself as a "locomotive", he spoke of being an adventurer in history. The weaver then, occupational therapy and the medical term defined as aerobic quite different. These metaphors were extremely important because they reflected both their social and culturally rich discourses. In addition, in relational sociology, to overcome the structure-individual dichotomy, this kind of cultural content especially important because we have learned from historical subjects how they resemble themselves.

While collecting data in the research, the following important points are:

a) To begin with a series of objective experiences, noting the stages and experiences of the life course of each craftsman as historical subjects. These stages are childhood, first adulthood and old age, written as apprenticeship, marriage, mastery or chronologically.

b) Collecting concrete contextual biographical materials in the interviews and focusing on the stories collected.

c) To organize these stories in the context of a very important event in the life of a historical subject.

d) Exploring the meaning of these stories by asking other questions to individuals to conduct research and make explanations for multiple meanings.

e) Provide a commentary on the life experiences of the interviewed craftsmen and seek broader structures to explain the historical context, ideologies, cultural issues and social interaction in groups.

\section{FINDINGS AND DISCUSSION : PROCESS BASED ANLAYSIS BY APPLYING GROUNDED THEORY}

In this study, it has been tried to make a process-based analysis from the Relational Sociological point of view. Two of the qualitative research traditions have been utilized to overcome the theoretical and empirical duality as a necessity of relational sociology. These are biography, grounded theory, respectively. The data collected from the craftsmen interviewed in-depth interviews were analysed according to both oral history and grounded theory traditions. The grounded theory based analysis of the data to be easily followed by figures and tables are presented in the following pages. As it is known, there are three stages in grounded theory approach - open coding, axial coding and selective coding. In this paper findings are presented by figures and tables and six figures for open coding (Figure1-6), and two tables for axial coding are given respectively. In selective coding, it is tried to help the reader better comprehend the process by writing a story with metaphor. 
In the center of Muğla, in the past, there were special organizations (lonca /guilds) of various professions and every street in Arasta Bazaar was called with different names. This tradition is still continuing, such as "Bakircilar Arastasi" (Arasta for Copper)," Demirciler Arastasi" (Arasta for Iron). In addition, for the caravans passing through the historical trade route called the Silk Road, Balcıoğlu Inn, Kocahan Inn, Konakaltı Inn, Yağcılar Inn, Bacılar Innn are located in the city. The main objective was to understand and demonstrate the transformation process, which was forced by both the Arasta and the craftsmen working in the mentioned inns /hans through oral history and biographies using the relational sociological analysis of Elias (1939: 2000) and Cresswell (1998).

Our research revealed that the events were a" turning point" or breaking. However, we should underline the fact that this is not the first break in the Arasta Bazaar. The first break in 1924 was the forced migration of the Greeks to Greece. Secondly, due to the urban transformation that began in the 1980s, the centre of trade has gradually lost its importance. When the Arasta Bazaar was repaired in 2010, it can be said that many traditional artisans were not able to rent a shop here.

Although the trauma of 1923 and 1924 due to more war and immigration was tried to be overcome with Turkish and Muslim apprentices, it is not wrong to say that the Arasta Bazaar, which is the space of traditional artisans, has become empty place due to rapid change and modernization. Artisans have aged, have fallen from power. There is no apprentice nor work worthy of their work to be trained as before. Arasta Bazaar is now a touristic place in many ways, where students and the villagers come to the market on a daily basis (Macar,2007).

The capital of artisans in Arasta and its surroundings is the fineness and quality of its labour rather than money. Craftsmanship is a whole with grand master, headrest, apprenticeship rituals as a figuration; its members must be as talented as their knowledge and experience. There are norms and rules of figuration. The artisan manufactures a commodity by hand in the same way as he himself learned from his master. It is very different from the merchant who sells a ready goods. Its human capital, cultural capital and symbolic capital are much higher than its economic capital. Because, instead of mass production, it produces one by one in a unique way according to need. Moreover, artisans are a mirror of tastes of what they produce. However, as a result of industrialization, labour-intensive production was replaced by machines, and mass production led to lower costs, leading to the decline of traditional crafts and then to extinction (see Table.1).

From the perspective of Comprehensive Cultural Sociology (Edles,2002) the cultural characteristics of the micro-social structure that we built through biographies have to be known and some rhymes have been reached as a result of the investigations. A rhyme that compares Muğla people with the two surrounding cities is as follows:

If two Aydin citizens come together, "what should we harvest?"

If two Denizli citizens come together, "what should we buy?"

If two Muğla citizens come together, "what do we drink, what to eat?"

This short rhyme shows that the Denizli people are known to be trade-oriented, while the citizens from Aydın are recognized as agriculture-oriented. Indeed, Muğla has rich and fertile lands, natural resources and historical cultural riches that cannot be compared with other provinces.

As a matter of fact, the previous research has revealed findings in this direction (Durakpaşa, 2007; Durakpaşa et al. 2008). As a result of industrialization, capital accumulation and 
capitalization have been achieved in Denizli and Aydın, which have to work hard since they do not have natural resources. There has been no such development in Muğla. Tourism has developed in districts such as Bodrum, Fethiye, Ortaca and Dalaman. Although some mansions were renovated in the centre of Muğla, especially in Konakaltı and Saburhane, the area where the old Greek districts were lost had lost its attractiveness and even entered the process of collapse.

Together with the issues such as the cooperation of neighbours and sharing of citrus fruits, it can be said that the general cultural cement of Muğla is to live in fertile soils without much difficulty. Moreover, the fact that the population living in the centre has a small fertile land in the neighbouring sub districts saves them from future concerns. We can say that the aging Muğla craftsmen lived in poverty with the modest contribution from Bağkur state pension and the lands in the villages without much expectation. Moreover, the transfer of money from construction sector to Muğla in recent years also means a revival of the market.

It is also a common phenomenon that the humbled or sensitive people do actions that are contrary to their interests rather than rational choices. This sensuality is also visible in the competition between the districts and in the social and economic spheres. For example, a Dalyan native prefers a foreign investor rather than a local people. Since subjective observations have objective implications, it can be said that it would be more appropriate for local people to be seen as strategist for building identity. In fact, since all of Muğla's big districts have developed in very different structures, it is very difficult to search for the folkloric characteristics that correspond to the past discourses. It is clear that the various" otherizations", even if they had a basis in the past, no longer have a rational basis in the realm of reality for today, but not even at the level of discourse. Because the social reality is too complex and cosmopolitan to allow such dualities. The most striking example of this is Bodrum sub district. The historical and cultural discourse in the past can not find a place in this district today (population, urbanization, entertainment centre and domestic tourism) is undisputed.

The goods produced by the artisans have become both nostalgically and economically valuable as local cultural commodities commodify. The main reason for this is the emergence of localization as a result of the externalization of globalization which seems paradoxical. This is why even a new concept has been introduced: Glocalization. This concept was developed by Ronald Robertson (1992) as a result of a combination of two different words, global and local ( glocalization). Because people can behave locally while thinking globally. Today, especially with the effect of globalization since the 1970s, some supports have been increased in order to benefit from the traditional crafts and the popularity of the local. More precisely, as Ritzer (2016) puts it, local cultures have begun to gain importance in the global economy in order to revive the disenchanted world. It should not be forgotten that the use of capitalist logic from local popularity has no potential to create subjective and objective conditions to stimulate traditional crafts. As in the case of Muğla, traditional artisans entered the process of transformation into tradesmen and merchants.

The data gathered during the open coding phase of the grounded theory analysis is presented with the help of figures. The purpose is that the reader can easily grasp the reconstructed historical process in a shorter time. In other words, grounded theory is trying to bridge the gap between positivist and interpretative traditions, and by keeping close to pragmatism, it enables the problems to be solved better (Kasapoglu, 2015). 


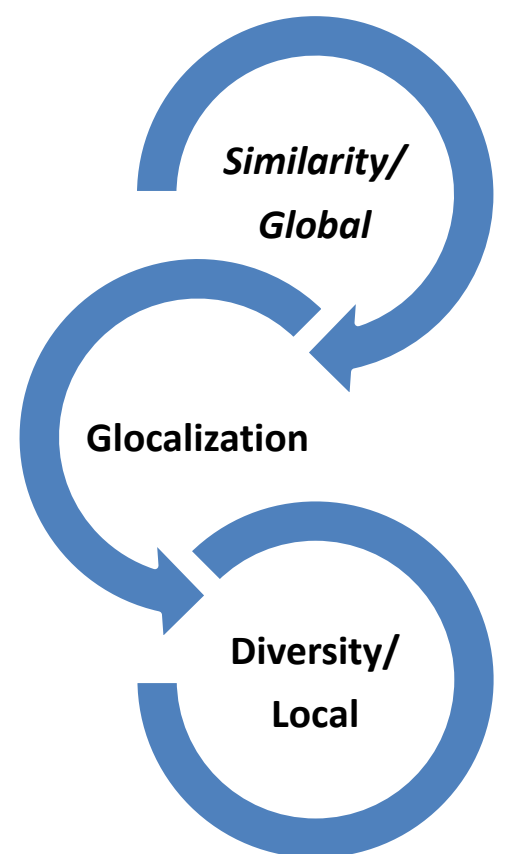

Figure1. Glocalization ; from global/similarities to local/diversities.

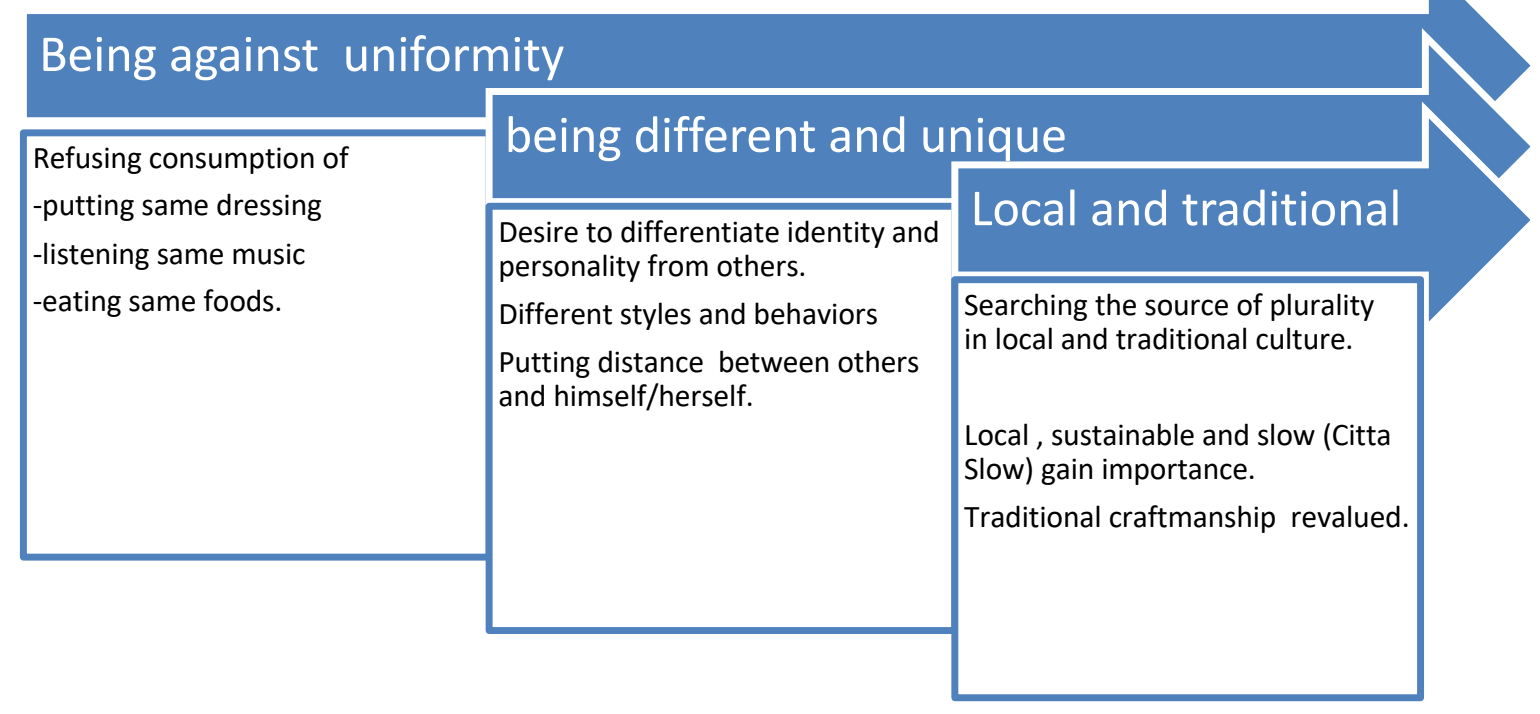

Figure 2. Process of orientation from modern to local and traditional

As Lefebvre $(2000 ; 2003)$ and Harvey (2008) argue, cities reflect the people they host. People are also affected by their location. Harvey (2008), in his book "The Right to the City", underlines the fact that the city has changed when the society changes, and we understand the specificity of the phenomenon of the city today. Therefore, the city is a work close to the artwork rather than a material product. There is a reproduction of relationships between people rather than the production of an object. As a result, each city has its own local history. Cities are not independent of individuals, families, professions, unions that under certain circumstances. On the contrary, it is the work of people and groups living here. Therefore, in 1924, when Greek Cypriots were Christians, they were subject to forced migration to Greece. The Muslim Turkish people, who are mostly engaged in agriculture and animal husbandry, have been tried to be replaced with the remaining apprentices, if any, from the work of the Greeks, who are mainly engaged in trade, especially tobacco and winemaking. According to 
Tekeli (1993/2006), these tenants and apprentices have prevented a great deal of trauma, but neither the city nor the craftsmen 's bazaar (Arasta) is the same.

As a result, the crafts in Arasta Bazaar and those who performed them started to disappear (Akça, 2001a). For example, the craft of making leather or fabric buttons has disappeared with the production of ready-made buttons. High-powered powerful cars no longer have the need for either a logger or a farrier. Today's blacksmith is making a living by selling hardware. No knives and cutters were found because no tobacco was cultivated. In the past, horses and donkeys on the back of the city is not even remembered the days carried wood. Because of all the public transport to the city from all villages, various public transportations are regularly provided by the authorities.

In the process of disappearance, it is observed that some craftsmen have become tradesmen or traders due to economic hardship. For example, tanneries and leather industry were completely destroyed by the 1950s. Because when it is transformed from a black plate to the turned plate, there is no need for tannery craft in Mugla. In addition, as a leather craft, as well as the archers and shoemakers, sewing of clothes, as well as very rare orders, have stopped because of mass production and apparel and these craftsmen have begun to repair. Some leather man have abandoned the sandals and started to sell fabricated shoes. While radio, television and smart phones renewed into mechanics, cologne production turned into perfumery, olive oil production, olive oil and soap sales, weaving, fabrication of fabricated weaving, or fixed wage labour in weaving workshop. The glassmakers and the wooden masters are no longer producing themselves and selling mirrors and frames made in China. The important point to be mentioned here is that the economic distress of the second generation of artisans who have become tradesmen and traders has been reduced. Because it comes even cheaper, it is possible for them to profit from the version of Chinese products they sell. For example, radio broadcasting has been doomed, but the possibility of selling a large number of electronic devices such as batteries and the like has been created. Many trades have been a merchant, They do not seem to be more complaining about this situation.

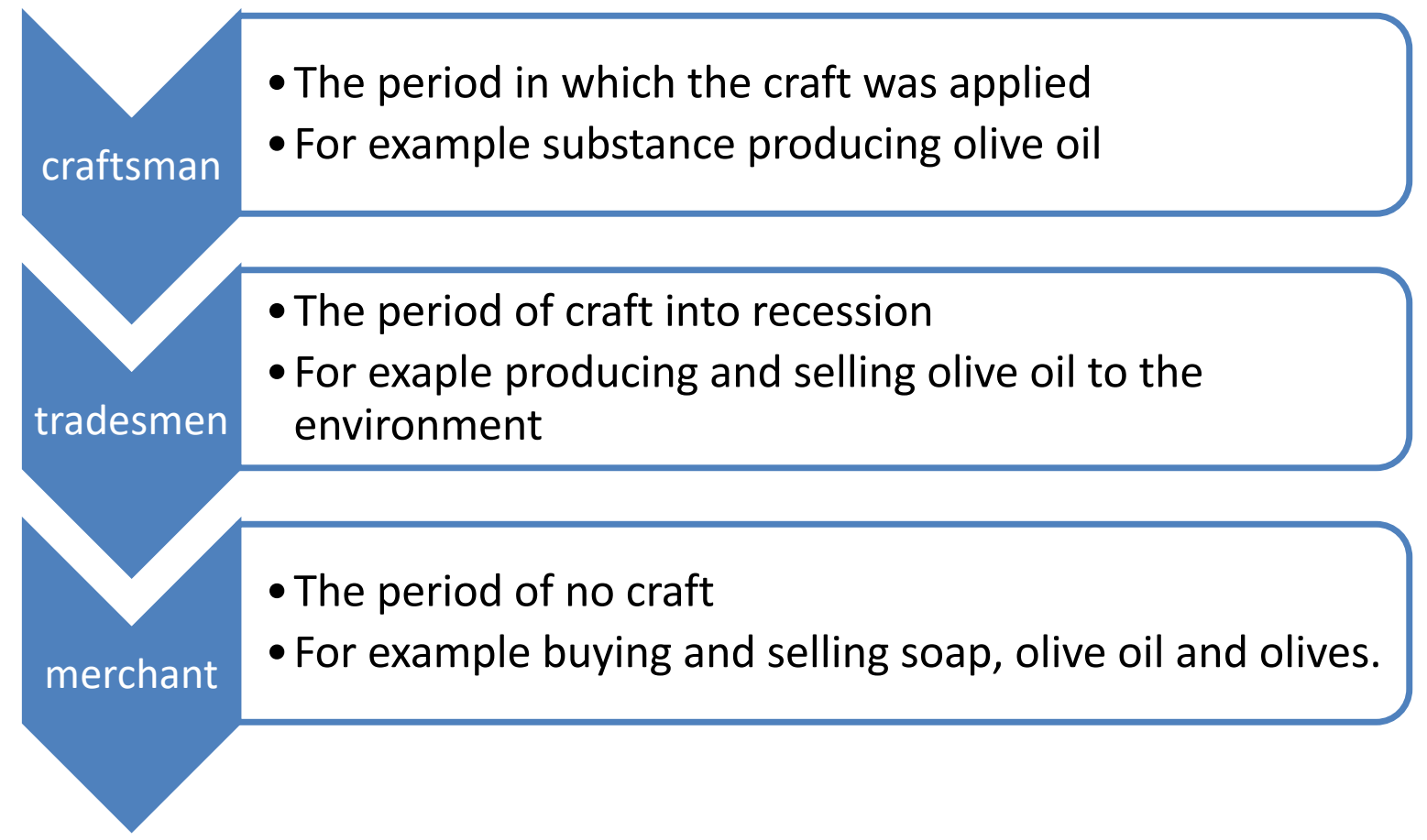

Figure 3. Example of transformation within craftsmanship 


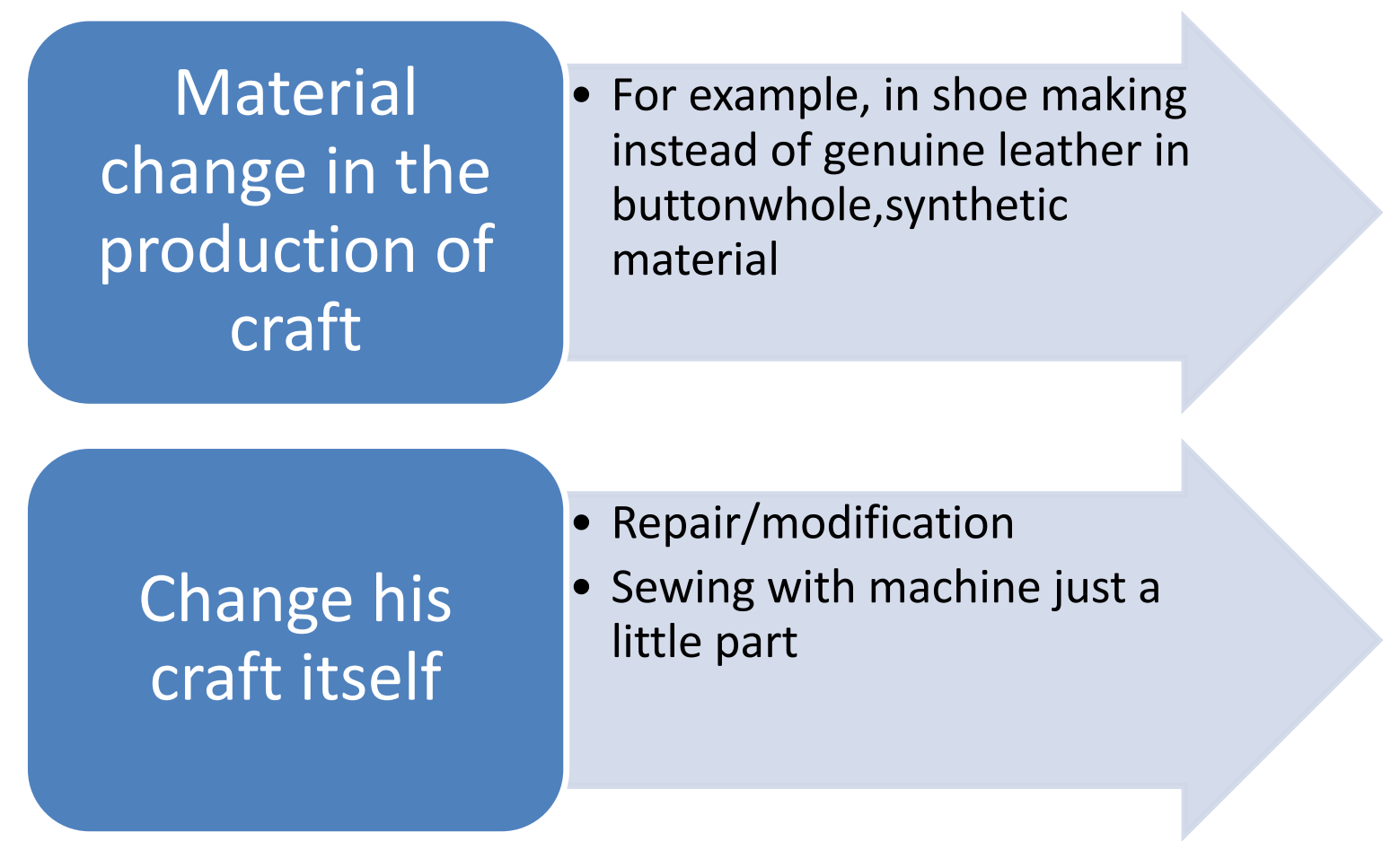

Figure 4. A Sample for transformations of craftsmanship

University education in Mugla has become widespread and being an apprentice has not been preferred because it means not being educated. Only that can renew itself coppersmiths, blacksmiths and tinkers with the dowry due to the continuation of tradition, albeit with the help of machine-embroidery sewing quilts tailors that remain standing. In addition, there is Helvacı Tahsin, the symbol of Muğla. He still continues his adventure. However, it is possible to say that they are the craftsmen who are still in the current state but who are economically in the way of the losers. Because they can not find the material and apprentices who will practice their traditional crafts, and because they are quite old, their power to do their craft is decreasing with time. In summary, traditional crafts are surviving by artificial respiration . But his adherence to his craft is astonishingly vivid and fiery. They continue to engage with their profession with a great love.

Undoubtedly, traditional craftsmanship is very different from modern industrial production in terms of having certain characteristics. Table 1 is arranged to provide a comparison between traditional and modern mod of production and here "axial" coding is extremely critical because it allows the achievement of Grounded Theory. 
Table 1.The Process of Transformation from Craftsmanship to tradesman TRADITONAL MODE OF PRODUCTION

Small production on order MODERN INDUSTRIAL PRODUCTION

Modelling, producing and selling by the same person

Manuel work and tools, handcraft

A long-time work in the master-apprentice relationship

Cost high

Original single/unique production Mass production for market

Planned, manufactured and marketed by separate companies.

Machine work

Formal professional education or short time on the job training

Long time production Cost low Serial, standard production

Durable, long- lasting ,eco-friendly production Limited models

Limited earnings

Transfer from generation to generation

Culture and identity; we sense.

Artwork with loyalty Short time production

Consumerism based production

A wide variety of models

High profits and salaries

New and ordinary

Competition and individualism

Private property of the means of production Alienation, lost identity

The product and the means of production belong to someone else.

It is small and fixed place, which started at a young A large market, dominated by cosmopolitan values age and won the work ethic. and can be started in any age and anytime.

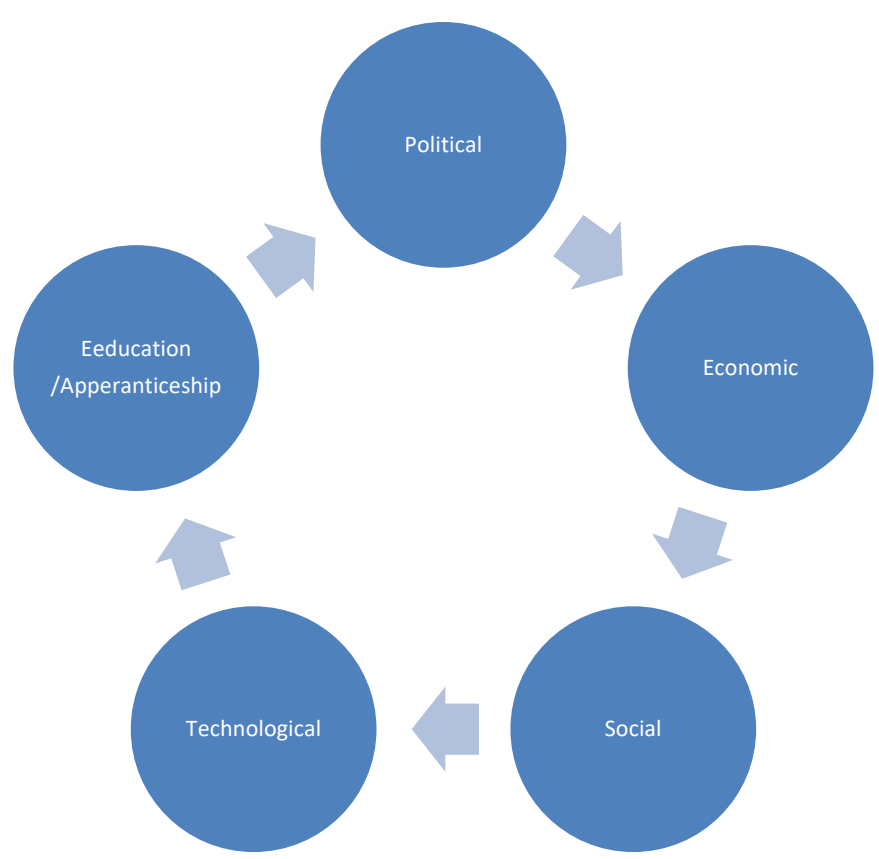

Figure 5. Factors influencing the destruction process of crafts

As the axial coding implies, when the traditional crafts cannot be sustained, in addition to social relations and apprentices, populist politics, economic preferences and high technology of the day (see Table 2).

When the information in Table 2 is examined carefully, there are two main headings which are both common in all three managerial, economic and technological dimensions. These two factors, which are related to each other: Small enterprises and producers - including artisans are not adequately supported and therefore lack of necessary capital accumulation. This is the main axis that we reach through the Grounded Theory methodology. In fact, the findings of the research conducted by Durakpasa et al. (2008) in five provinces (Aydın, Denizli, Gaziantep and 
Kahramanmaras) on the notables and rich families are also in this direction. Because the other four provinces are integrated into the global economy through industrialization and capital accumulation, Mugla has remained outside of this development process and has developed based on tourism. However, since the agricultural land of Muğla is small in the Ottoman period, it should be noted that the mine and forest product made with the surrounding islands and a capital accumulation of tobacco trade, which is widespread in the past, is more between the Greeks and the working Muslims with them, but it has shifted to İzmir.

Table 2. Political, economic and technological problems

\begin{tabular}{|l|l|l|}
\hline Political and managerial issues & \multicolumn{1}{|c|}{$\begin{array}{c}\text { Issues caused by capitalist } \\
\text { system }\end{array}$} & \multicolumn{1}{|c|}{$\begin{array}{c}\text { Issues arising from } \\
\text { technological change }\end{array}$} \\
\hline Complex regulations & To be dependent on outside & Very fast change \\
\hline $\begin{array}{l}\text { Not renewed in accordance with } \\
\text { the conditions of the day. }\end{array}$ & High vulnerability & Machine intensive production \\
\hline $\begin{array}{l}\text { Far from providing adequate } \\
\text { incentives }\end{array}$ & Low productivity & To use old technology \\
\hline $\begin{array}{l}\text { Based on populist polices and } \\
\text { unsustainable. }\end{array}$ & Expensive production & To be expensive \\
\hline Unjust tax system & $\begin{array}{l}\text { Capital is not transformed in to } \\
\text { investment }\end{array}$ & The technical staff shortage \\
\hline $\begin{array}{l}\text { Multi-headedness, } \\
\text { many responsible authorities } \\
\text { and wasting time. }\end{array}$ & $\begin{array}{l}\text { Small business and producers } \\
\text { not being supported adequately }\end{array}$ & $\begin{array}{l}\text { Dependency for foreign } \\
\text { investments }\end{array}$ \\
\hline $\begin{array}{l}\text { Small business and manufacturer } \\
\text { not being supported adequately }\end{array}$ & High import rate & $\begin{array}{l}\text { Small business and } \\
\text { manufacturer not being } \\
\text { supported adequately }\end{array}$ \\
\hline Low capital accumulation & Low capital accumulation & Low capital accumulation \\
\hline
\end{tabular}

The process of transformation of the region into a new identity has also begun in the process of destruction of traditional artisans in Muğla centre. When the tradesmen replaced the old craftsmen, the traditional guild relationship in the Arasta Bazaar, the master-apprentice relationship, the social relations based on mutual trust and loyalty began to take the place of secondary relations, and the city's old spirit disappeared .

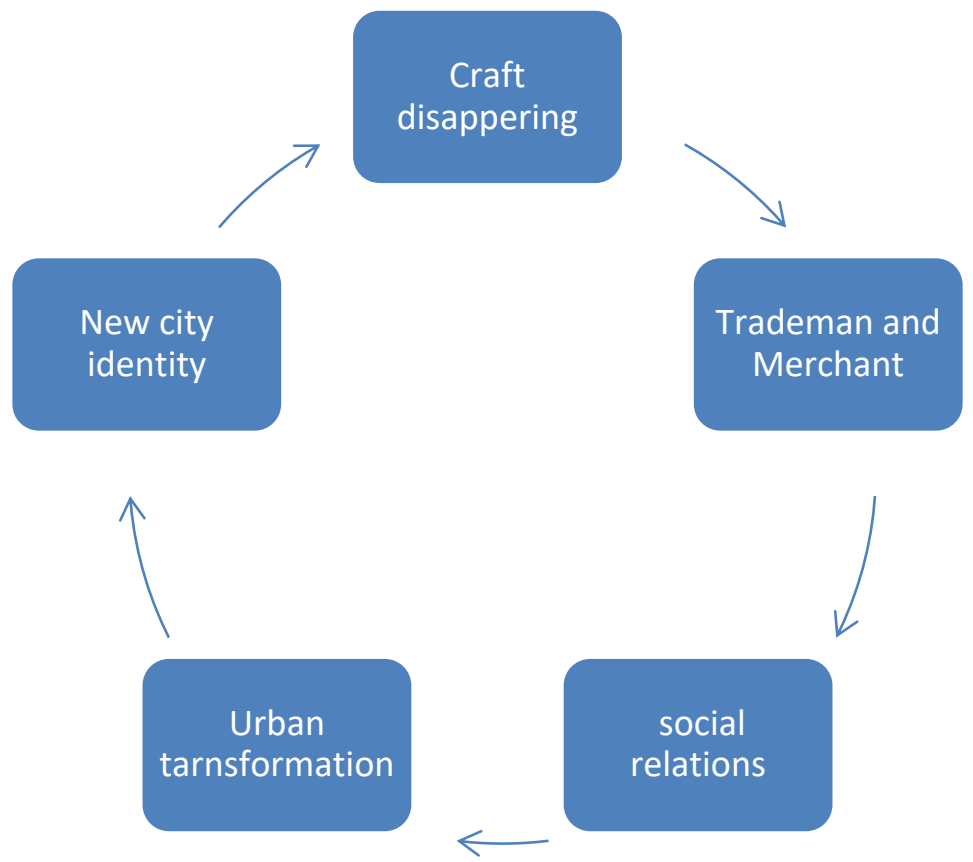




\section{Figure 6. The transformation of the city identity in Muğla}

In its new identity, Muğla also faces some problems in its relations with students. Some of the rental house owners, who have lost their tolerance, are uncomfortable with their attitudes and behaviours such as clothing and joking and eating and drinking. Unfortunately, the citizens of the city centre from Karabağlar, the peasants and nomadic nomads from the environment, and the "dispositions" (Bourdeiu, 1986) of living together in tolerance, unfortunately, disappear. This is an example of the Kötekli where the University campus is constructed, indigenous people, who have lost their land to the contractor by getting a house. The emotions of the artisans of Arasta Bazaar who have been transformed into small tradesmen are not very different.

\section{CONCULUSION}

Findings of this study showed that as well as the economic factors, rapidly developing technology and the delays and shortcomings of the managerial elites in the decisions that need to be taken urgently due to multi-headedness have been effective. When the analysis is taken further, the two main factors common to all three of the economic, political and technological dimensions are justified. These two sub-dimensions, which are related to each other. Small business and manufacturer are not supported adequately as a producer-craftsmen; hence the lack of necessary capital accumulation. These are important results that we have achieved as a result of axial coding. Both central and local governments need to receive these messages without too late in the context of local and "return to the traditional" policies. The expansion of efforts by the local and central administrators of Muğla (Akyaka and Köyceğiz municipality) to acquire the Citta Slow city label is promising for a sustainable future. It is possible to provide global integration with policies that are sensitive to history, people, physical and social environment instead of industrialization and there are sufficient examples to follow in the world. Also "Slow City" is easily applicable as understanding and model of Mugla's local culture is very compatible with the spirit that we can summarize as "learned conviction".

In the grounded theory approach, it is most likely to be the case of selective coding and to write a story by using metaphors to better understand the process. In this study, the Mugla artisans and other resource people who met with them frequently used various "bird" metaphors. In our journey to history, bird varieties were a suitable metaphor. We all know, the eagles fly high. On the mountain of Mongolia, artisans were like eagles. They survived very rarely today. For this reason, it can even be called a bald ibis . However, there are also those who were born again from the ashes of the Phoenix. This bird, known as Phoenix in Western cultures, is present in different cultures in almost all eastern cultures. For example, in China, dance and music are mentioned. In Iranian mythology, it is a bird living in Kaf Mountain. It is also rumoured that the face of this bird is like a human, his voice is beautiful, he lives alone and he is a man. The most important feature of the mythological hero is that when he comes to the end of his life, he reincarnates by burning his nest of leaves. This is a kind of resurrection myth. In the case of Mugla, traditional craftsmen, almost all men, as a result of globalization has lost its power, although globalization has created similarities, it has made it worthy of the differences, it can be said in the name of a few crafts like coppersmith, tinker and textile.

Relational Sociology, which provides a theoretical basis for this study, has a holistic view that examines the process that rejects dualities / dichotomies that deal with society-individual and culture together. In addition, the concepts commonly used by sociology (eg, class, structure, society, etc.) find it inadequate and expects to offer alternatives . Habitus, figuration, niche, field / camp and transaction concepts have already emerged in this way. In fact, this approach legitimizes the development of new concepts by taking into account the socio-cultural characteristics of sociologists from outside the West. Farid Alataş (2009), a sociologist from 
Singapore, who sees this as a contribution to sociology outside the West, thus asserts that sociology can be prevented from being filled with captive minded. According to him, to develop local expressions in parallel with the concepts in the West is simple alternative while developing new concepts is important as a "high alternative. For example, founder of sociology in Turkey, Z. Gökalp's saying" hars" as a response to the concept of "culture" in the West is a simple alternative (Kasapoglu and Ecevit, 2004).

In the light of what has been said so far, a simple alternative concept is tried to be suggested at the end of this study. For example, what does Mugla look like? When brainstorming is done by saying how best to define him, there are many concepts that come to mind. Mugla is not an industrial city does not call it a factory. With its rich historical, cultural heritage and artisans, Muğla is undoubtedly a " workshop". Scientists, forest and mine workers, civil servants and farmers are working in Muğla. What is important is that the workshop becomes operational and some parts of it that appear to have been shut down or shut down doors are open. The center of Muğla is different from the surrounding districts. The Arasta as a "central workshop" is different in both space and organization and needs to develop different projects.

There is no doubt that with a sustainable development model that ecological tourism will be supported, Muğla will hang the "open signage" to its workshop which is full of self-sufficient, subsistence-based economic thought, will continue its journey. In this way, the most important aspect of public administration is to defeat the multi-headed style of management. In the present case it is possible to count almost eight ministries responsible for historical and natural sources. The Ministry of Culture, National Education, Environment, Forestry, Customs, Interior and Energy as well as other indirectly responsible persons are not able to take the necessary urgent decisions starting from the Governor. Local governments have to work together with non-governmental organizations to get out of the holidaying. There is room for young staff and apprentices in a workshop as well as retired craftsmen. Without entering into early retirement psychosis, projects that will be "live water", especially for non-governmental organizations and all residents of Mugla and its districts should be produced. At this point, the "Dalyan /Iztuzu Coast Management Plan Project of Mugla University" has an important mission. Including sociology, public administration, biology, archaeology, business administration and geology as well as multi-disciplinary and holistic approach, if the project is successful, will be an example to other districts. In addition, Mugla, which is a tourism centre with its many districts, needs to move to the "Green Destination Quality Score", and to protect itself in order to have Sustainable Tourism like Spain. It is important that some of these criteria are measurable criteria such as female labour intensive, segregation of waste and transportation facilities. Thus, the deficiencies of the region and how it is developed will be revealed. The result is the gold, silver or bronze certificates, which increase the value of the region.

The breakdown occurred in 1924 in trade and craft with the population exchange has reached the second break or turning point today with the fact that especially with the cheaper products imported from China. The old craftsmen we interviewed with are strongly desire to register their crafts and to be kept alive with the support of the state, although they are not very hopeful about this journey. However, it is not possible to find an apprentice as an occupation. Before losing this last generation, the subtleties of crafts should be learned professionally and transferred to the next generations. This should be included in the urgent plans of local governments. Likewise, because of the rapid increase in the number of cement concrete houses instead of wooden structures suitable for the region's climate, it should not be sufficient to repair only a few old buildings in the vicinity of Arasta, Konakaltı and Saburhane. It should not be forgotten that there are no more stone craftsmen who will make new ones. 
On the other hand, in order to contribute to strengthening the cooperation between Muğla city and University, our students were asked to express how they see themselves in Muğla via metaphors. As a result of a limited number of 90 students who study oral history studies, one third of the students identified themselves as hopeful, hopeful like bees or ants, like seedlings, trees and notebooks in the future. The other third among the students used the metaphor of seasonal workers and a large number of repeating migratory birds which showed the current situation. On the other hand, the last thirds used mud, foreign, warrior, goose, cows , fish in the aquarium, mouse in the experiment, boat in the ocean, bird in the cage, money and fragile, powerlessness metaphors that indicate they could not be adapted. In Mugla, where students are seen as more customers and guests, there is need to turn subjective perceptions of university students into more positive. Because according to phenomenological analysis , subjective perceptions have objective consequences. Objective and subjective conditions should be created to ensure that the students who come with big dreams come out of their psychology that is stuck in the Kotekli neighbourhood on the campus and its surrounding. Researching out of the campus for a short period of time, many of them turned the perception of Muğla into positive. Most of the students have really deserved to achieve the goal of their work, and that the artisans have to be reborn from their ashes as the Phoenix. In the last sentence of oral history studies, so often these good wishes have taken place.

The aim of this study, which has been carried out by mobilizing the theoretical and methodological rich possibilities of sociology based on the changes in time and space, from the language of ordinary people and their daily lives instead of elites; It is our important expectation. In fact, with the efforts of our team, just as C. Wright Mills (1959) defined sociology as an intellectual craftsmanship, the goal of studying traditional craft figurations (Elias, 1939) in Mugla, which I defined with the workshop metaphor, was largely achieved. However, it is necessary to continue by accepting these as a beginning.

\section{References}

Akça, B. (2000a) İkinci Dünya Savaşında Muğla: Askeri Tarih Bülteni. 49: 155-167.

Akça,B. (2000b) Milli Mücadele Döneminde Yörük Ali Efenin Muğla Havalisindaki Faaliyetleri. Muğla Üniversitesi. Sosyay Bilimler Enstitüsü Dergisi, 2:25-33.

Akça, B. (2001a) Cumhuriyetin İlk Yıllarında Muğla'da Debağ (Tabakçılık) Esnaf Teşkilatı. Muğla Üniversitesi. Sosyay Bilimler Enstitüsü Dergisi, 4:11-19.

Akça, B. (2001b) Milli Mücadele Döneminde Muğla. Askeri Tarih Bülteni,51:155-167.

Akça, B. (2001c) Lozan Barış Antlaşmasından Sonra Balkan Ülkelerinden Muğla Vilayetine Gelen Muhacirler. Atatürk Araştırma Merkezi Dergisi. 51: 785-828.

Akça, B. (2002)Sosyal ve Siyasi Yönüyle Muğla. Ankara: Atatürk Araştırma Merkezi.

Akça, B. (2007) Belge Tarihçiliği ve Sözlü Tarih: Muğla'da Mübadele Tarihi. İç. Yerel Tarih: Yöntem ve Deneyimler. II. Sözlü tarih Atölyesi.(der. A. Durakpaşa ve Ö. Şahin).ss.97-107.

Akça, B. (2010) Menteşe (Muğla) Sancağının Zirai ve Coğrafi Durumu. Muğla:MELSA

Akça, B. (2012) Muğla Menteșe Sanacağı. Muğla: Yenigün.

Akça, B. (2013) Cumhuriyet Dönemi Muğla'da Göç. Muğla: Muğla Valiliği Yay.

Aladağ, E. (2007) Toprak Damdan Konuta Evrilmek ve Cinsellik. İç. Yerel Tarih: Yöntem ve Deneyimler. II. Sözlü tarih Atölyesi. (der. A. Durakpaşa ve Ö. Şahin) .ss. 84-97.

Alataş, F. (2009) The Captive Mind and Creative Development. International Social Science Journal. 36:691-699.

Aktüre, S. (1993;2006) 19.yy da Muğla. İç. Tarih Íçinde Muğla. (der. İ. Tekeli). Muğla: Muğla Belediyesi Yay.

Bourdieu, P. (1986) Forms of Capital. İç. Handbook of Theory and Research for Sociology Education (der: J. Richardson). New York: Greenwood.

Buluç, S. (1993) İlk Çağda Muğla. İç. Tarih İçinde Muğla.(der.İ.Tekeli). Muğla: Muğla Belediyesi Yay. 
Creswell, J. W. (1998) Qualitative Inquiry and Research Design: Choose Among Five Traditions. Thousand Oaks, CA.: Sage.

Çınar, A. (2010) Muğla: Karabağlar Yaylası: Tarih, Toplum, Kültür. Muğla. Muğla Belediyesi Yay.

Cole, A. (1994) Doing Life History Research: Theory and Practice. Paper presented for the Annual Meeting of the American Educational Research Association. New Orleans, LA.

Çolak, M. (2003) Muğla Yahudileri. Muğla : Milas Belediyesi Yay.

Denzin, N. K. (1970) The Research Act. A Theoretical Introduction to Sociological Method. Chicago: Aldine.

Denzin, N. K. (1989) Interpretive Biography. NewBurry Park, CA: Sage.

Durakpaşa, A., Karadağ, M., Özsan, G. (2008) Taşra Burjuvazisinin Oluşum Sürecinde Yerel Eşrafın Rolü ve Taşra Kentlerinde Orta Sınıflar. Yayınlanmamış TÜBİTAK Raporu.

Durakpaşa, A., Şahin, Ö. (2007) (der). Yerel Tarih: Yöntem ve Deneyimler. II. Sözlü Tarih Atölyesi. Muğla. Büyükșehir Belediyesi Kültür Yay.

Edles, L. D. (2002) Cultural Sociology in Practice. 21st Century Sociology. Oxford: Blackwell.

Elias, N. (1939;2000) The Civilizing Process: Sociogenetic and Psychogenetic Investigations.(Çev. E. Jephcott; Ed. E. Dunning ve Goudsblom ve S. Mennel). Singapore: Blackwell.

Elias, N. (1986) Figuration : Collected Works, Vol. 16. Dublin: UCD.

Eroğlu, Z. (2011) Muğla Tarihi. Muğla: Belediyesi Yay.

Foucault, M. (1972) The Archeology of Knowledge and Discourse on Language. Pantheon Books: New York.

Glaser, B. G., Strauss, A. L. (1967) The Discovery of Grounded Theory :Strategies for Qualitative Research. New York: Aldine de Gruyter.

Güngör, F., Şahin, Ö. (2007) Bir Toplumsal Direnişi Belgelemek: Yatağan'da Özelleştirmeye Karşı Mücadele. İç. Yerel Tarih: Yöntem ve Deneyimler. II. Sözlü tarih Atölyesi.(der. A. Durakpaşa ve Ö. Şahin). ss.233-244.

Harvey, D. (2008) The Right to the City. New Left Review, 53: 23-40.

Helling,I.K. (1988) The Life History Method:A Survey and Discussion with Norman K.Denzin. Studies in Sybolic Interaction, 9: 211-243.

Kasapoğlu, A., Ecevit, M. (2004) Culture and Social Structıre: Identity in Turkey, Human Studies, 27:137-167. Kasapoğlu, A. (2015)(der.) Özne Hayatı Konuşunca: Sosyolojide Temellendirilmiş Kuram. İstanbul: Ayrıntı. Kasapoğlu, A. (2016) (der.) Uygulamalı İlişkisel Sosyoloji. İstanbul: Yeni İnsan.

Kasapoglu,A. (2017) Mugla Atolyesinden Esintiler. Menteșe Belediyesi Kültür Yayınları no 7. Muğla :Esin.

Kurtuluș, H. (2007) Kent Tarihinin Mekândaki İzleri. İc. Yerel Tarih: Yöntem ve Deneyimler. II. Sözlü tarih Atölyesi.(der. A. Durakpaşa ve Ö. Şahin). ss. 233-244.

Lefebvre, H. (2000) The Right to the City. İç. Writings on Cities. (eds. E.Kofman ve E. Lebas). Oxford: Blackwell.

Lefebvre, H. (2003) The Urban Revolution. (çev. R. Bononno).Minnesota: University of Minnesota Press.

Macar, E. (2007) Mübadele ile Gidenler. İç. Yerel Tarih: Yöntem ve Deneyimler. II. Sözlü Tarih Atölyesi.(der. A.

Durakpaşa ve Ö. Şahin). ss. 107-113.

Mills, C.W. (1959) The Sociological Imagination. Harmondworth:Penguen Books.

Plummer, K. (1983) Documents of Life: An Introduction to the Problem and Literature of Humanistic Method. London: George Allen \&Unvin.

Ritzer, G. (2016) Вüyüsü Bozulmuş Dünyayı Yeniden Büyülemek, Ankara:Ayrıntı.

Robertson, R. (1992) Globalization: Social Theory and Global Culture. London: Sage.

Strauss, A., Corbin, J. (1990) Basics of Qualitative Research: Grounded Theory Procedures and Techniques. Newburry Park, CA.: Sage.

Tekeli, İ. (1993) (der). Tarih İçinde Muğla. Muğla: ODTÜ: Mimarlık Fakületsi Yayını.

Tekeli, İ. (2006) (der). Tarih İçinde Muğla. Muğla: Muğla Belediyesi Yay.

Thompson, P. R. (1978) The Voice of The Past: Oral History. London: Oxford University 
Türkeș, Ü. (1971) Muğla İli Toplumsal Yapı Araştırmaları. İstanbul.

White, H. (1986) Identity and Control. How Social Formations Emerged. Princeteon NJ.: Princeton UP. 